\title{
lodine concentration in Norwegian milk and dairy products
}

\author{
Lisbeth Dahl $^{1 *}$, Jill A. Opsahl ${ }^{1}$, Helle M. Meltzer ${ }^{2}$ and Kåre Julshamn ${ }^{1}$ \\ ${ }^{1}$ National Institute of Nutrition and Seafood Research (NIFES), PO Box 176 Sentrum, NO-5804 Bergen, Norway \\ ${ }^{2}$ Division of Environmental Medicine, Norwegian Institute of Public Health, PO Box 4404 Nydalen, NO-0403 Oslo, \\ Norway
}

(Received 15 July 2002 - Revised 11 April 2003 - Accepted 22 April 2003)

\begin{abstract}
The present study was conducted to determine the iodine concentration in Norwegian-produced milk and a selection of dairy products. The iodine concentration of eighty-five samples of milk and dairy products was analysed by inductively coupled plasma-MS. Low-fat milk and organic milk were sampled from nineteen and seven different locations in Norway, respectively, during the summer and winter season of 2000. Other milk and dairy products were chiefly collected during the summer season. Low-fat milk from the summer season had significantly lower median iodine concentration $(88 \mu \mathrm{g} / \mathrm{l}$, range $63-122 \mu \mathrm{g} / \mathrm{l})$ compared with low-fat milk from the winter season $(232 \mu \mathrm{g} / \mathrm{l}$, range 103-272 $\mu \mathrm{g} / \mathrm{l})$. The median iodine concentration of organic summer milk $(60 \mu \mathrm{g} / \mathrm{l})$ was significantly lower than the iodine concentration of organic winter milk $(127 \mu \mathrm{g} / \mathrm{l})$. There were no significant differences in the low-fat-milk samples with regard to geographical sampling location. Whey cheese (Tine Gudbrandsdalsost) iodine concentration was significantly higher $(803 \mu \mathrm{g} / \mathrm{kg})$ than the median iodine concentration in casein cheeses such as Jarlsberg and Norvegia of 201 and $414 \mu \mathrm{g} / \mathrm{kg}$, respectively. With a recommended iodine intake of $150 \mu \mathrm{g} / \mathrm{d}$ for adults, a daily intake of 0.4 litres milk meets the requirement with $25 \%$ during the summer and more than $60 \%$ during the winter season. Thus, milk and dairy products are important determinants of iodine intake in Norway.
\end{abstract}

Iodine: Milk: Dairy products: Inductively coupled plasma-mass spectrometry analysis: Norway

The trace element iodine is essential for normal activity of the thyroid hormones thyroxine and triiodothyronine. Clinical and sub-clinical manifestations of iodine deficiency, termed iodine-deficiency disorders, affect all stages of human life and are characterised by a variety of conditions (Hetzel, 1983; Delange, 1994). Iodine deficiency remains the single greatest cause of preventable brain damage and mental retardation worldwide (World Health Organization, 1996). Means to alleviate iodinedeficiency disorders are therefore of both national and international interest. Salt iodisation has been recommended as the preferred strategy to control and eliminate iodine-deficiency disorders by the WHO (World Health Organization, 1994).

Data on the iodine nutrition of the Norwegian population are very scarce. Iodine deficiency has been eradicated in Norway since 1950, when fortifying cattle fodder with iodine was started (Frey, 1986). Milk and dairy products have since then been considered to be the primary source of iodine in the Norwegian diet (Frey et al. 1993). The only good natural source of iodine is seawater fish and other marine products (Julshamn et al. 2001). Although Norwegians traditionally have had a high average intake of fish, this did not secure the iodine intake of inland population groups without access to the sea. Thus goitre used to be widespread wherever fish intake was low (Frey, 1986).
Food regulations permit the addition of $5 \mu \mathrm{g} \mathrm{I} / \mathrm{g} \mathrm{NaCl}$ to salt (Ministry of Health, 2002); however, the amount is too low to contribute significant amounts of iodine compared with milk and fish. This is due to the fact that only some brands of table salt are fortified with iodine and industrial salt used in food production is not fortified with iodine (NNR, 1996). With an estimated average intake of $3 \mathrm{~g}$ table salt/d, iodine-fortified salt only contributes $15 \mu \mathrm{g}$ I, if used.

There has never been a systematic monitoring of the iodine concentration of Norwegian foods or the iodine intake from the Norwegian diet. The most recent studies were performed in 1971-2 and in 1985 in small groups of Norwegians and showed satisfactory iodine excretion in urine (Frey et al. 1993).

The iodine content of animal feedstuff is controlled by legislation in Norway. The fortification of cow fodder with $2 \mathrm{mgI} / \mathrm{kg}$ as calcium iodate, $\mathrm{Ca}\left(\mathrm{IO}_{3}\right)_{2}$, to protect animal health (Ministry of Agriculture, 2002) has also provided a source of iodine in human diets (Frey, 1986). In 1996, a new regulation in Norway was passed ensuring that cattle should spend at least 8 weeks each summer out of doors, grazing naturally (Ministry of Agriculture, 1996). The regulation probably contributes to better animal welfare, but also makes the animals' feed more vulnerable to local soil-mineral conditions. 
Analysis of iodine concentrations in foods in other countries has shown that the iodine content of dairy products varies according to season of the year and geographical origin of the milk (Baumann, 1990; Pennington, 1990; Lee et al. 1994; Karl \& Munker, 1999; Larsen et al. 1999; Ministry of Agriculture, Fisheries and Food, 2000). The aim of the present study was to determine the iodine concentrations in Norwegian-produced milk and a selection of dairy products, and discuss eventual variations in results in relation to sampling site, seasonal production and production method.

\section{Materials and methods}

\section{Collection of samples}

Low-fat-milk samples ( $15 \mathrm{~g}$ fat/l) were collected from nineteen different locations in Norway (Fig. 1 and Table 1) during the winter and the summer seasons of 2000. Organic milk (not homogenised; $15 \mathrm{~g}$ fat/l) was sampled from seven different locations during the same period (Fig. 1 and Table 2). Organic milk is produced by farmers who practise organic farming. The organic products are controlled and certified by Debio, a government-approved authority, which also provides a guarantee seal for the organic agricultural production in Norway (Debio, 2003). In Norway there are few dairies producing organic milk and the geographical range is therefore less than for non-organic milk.

The choice of low-fat milk was based on the widespread consumption of low-fat milk in Norway i.e. $54 \%$ of the total milk sales (AC Nielson, unpublished results). In addition, the iodine concentration of milk is shown not to vary in relation to the fat content in different types of milk (Varo et al. 1982; Lee et al. 1994). The dairies were divided into five groups dependent on geographical region in Norway: north, central, west, south and east (Fig. 1).

Furthermore, processed dairy products were collected during the summer season. Among the samples analysed were extra-low-fat milk ( $7 \mathrm{~g}$ fat/l), curdled milk (38 g fat/1) and probiotic milk with Lactobacillus rhamnosus GG (Biola; TINE, Oslo, Norway; $15 \mathrm{~g}$ fat/l), dairy products such as yoghurt (32 $\mathrm{g}$ fat/l), soured cream (200 g fat/l) and cheese. Several types of cheese were analysed, i.e. Jarlsberg $(270 \mathrm{~g}$ fat $/ \mathrm{kg})$, Norvegia $(270 \mathrm{~g}$ fat $/ \mathrm{kg})$ and whey cheese (Tine Gudbrandsdalsost; $290 \mathrm{~g}$ fat $/ \mathrm{kg}$ ). These three cheeses account for approximately $60 \%$ of the cheese sales in Norwegian grocery shops (AC Nielson, unpublished results).

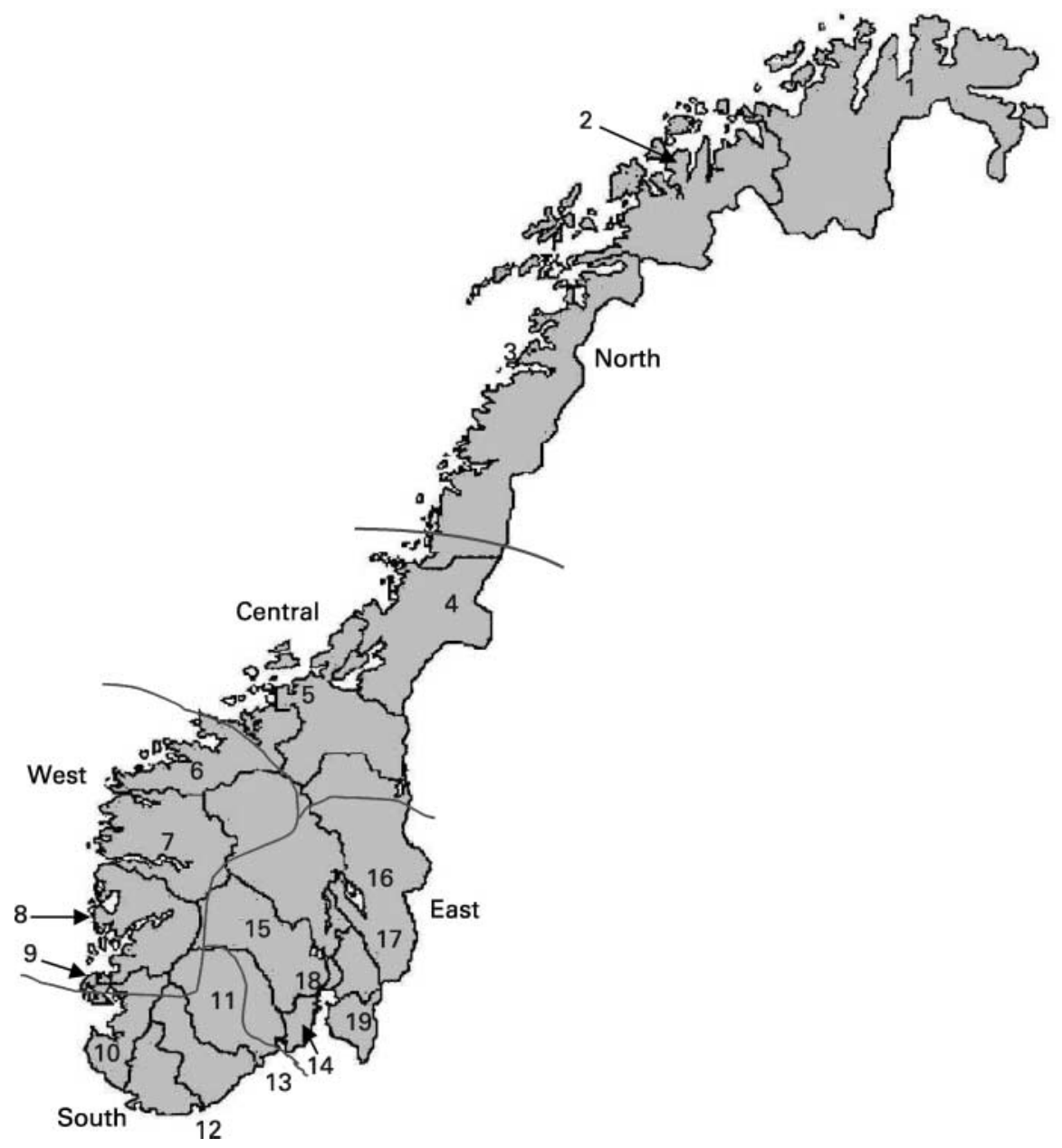

Fig. 1. Map of Norway showing positions of the nineteen dairies where low-fat milk and organic milk were sampled. For locations of the dairies 1-19, see Table 1. 
Table 1. Geographical location and iodine concentration of low-fat milk and organic milk sampled during the winter and summer seasons of 2000 in Norway

\begin{tabular}{|c|c|c|c|c|}
\hline \multirow[b]{3}{*}{ Geographical location§ } & \multicolumn{4}{|c|}{ Iodine concentration $(\mu \mathrm{g} / \mathrm{l})$} \\
\hline & \multicolumn{2}{|c|}{ Low-fat milk } & \multicolumn{2}{|c|}{ Organic milk $\ddagger$} \\
\hline & Winter & Summer & Winter & Summer \\
\hline North Mean & 252 & 104 & & \\
\hline Tana (1) & 237 & 88 & & \\
\hline Tromsø (2) & 246 & 106 & & \\
\hline Bodø (3) & 272 & 117 & & \\
\hline Central Mean & 248 & 100 & & \\
\hline Tunga (4) & 270 & 101 & & \\
\hline Høgset (5) & 226 & 98 & & \\
\hline West Mean & 237 & 94 & & \\
\hline Ålesund (6) & 269 & 105 & 163 & 62 \\
\hline Byrkjelo (7) & 223 & 76 & & \\
\hline Bergen (8) & 247 & 121 & & \\
\hline Haugesund (9) & 207 & 73 & 115 & 28 \\
\hline South Mean & 225 & 72 & & \\
\hline Sola (10) & 232 & 73 & & \\
\hline Setesdal (11) & 220 & 78 & 127 & 87 \\
\hline Kristiansand (12) & 249 & 73 & & \\
\hline Porsgrunn (13) & 199 & 63 & 264 & 60 \\
\hline East Mean & 214 & 99 & & \\
\hline Sem (14) & 260 & 81 & 35 & 36 \\
\hline Ål (15) & 103 & nd & & \\
\hline Hamar (16) & 232 & 117 & & \\
\hline Odal (17) & 225 & 85 & 365 & 68 \\
\hline Oslo (18) & 213 & 88 & & \\
\hline Indre Østfold (19) & 253 & 122 & 102 & 17 \\
\hline Mean & $231^{*}$ & 93 & $167 \dagger$ & 51 \\
\hline SD (all) & 34 & 17 & 111 & 25 \\
\hline
\end{tabular}

nd, not determined.

* Mean value was significantly different to that for low-fat milk from the summer season $(P<0.001)$

† Mean value was significantly different to that for organic milk from the summer season $(P=0.02)$.

$\ddagger$ Organic milk was sampled at only seven different locations.

$\S$ The numbers in parentheses relate to the positions on the map (Fig. 1).

Table 2. lodine concentration in milk $(\mu \mathrm{g} / \mathrm{l})$ and dairy products $(\mu \mathrm{g} / \mathrm{kg})$ produced in Norway during the winter and summer seasons of 2000

(Median values and ranges)

\begin{tabular}{lccc}
\hline Product & $n$ & Median & Range \\
\hline Low-fat milk, winter $(\mu \mathrm{g} / \mathrm{l})$ & 19 & $232^{*}$ & $103-272$ \\
Low-fat milk, summer $(\mu \mathrm{g} / \mathrm{l})$ & 18 & $88 \ddagger$ & $63-122$ \\
Organic milk, winter $(\mu \mathrm{g} / \mathrm{l})$ & 7 & $127 \dagger$ & $35-365$ \\
Organic milk, summer $(\mu \mathrm{g} / \mathrm{l})$ & 7 & 60 & $17-87$ \\
Extra-low-fat milk, summer $(\mu \mathrm{g} / \mathrm{l})$ & 5 & 103 & $66-128$ \\
Extra-low-fat milk, winter $(\mu \mathrm{g} / \mathrm{l})$ & 1 & 234 & \\
Curdled milk $(\mu \mathrm{g} / \mathrm{l})$ & 6 & 114 & $100-221$ \\
Probiotic milk with LGG\|l $(\mu \mathrm{g} / \mathrm{l})$ & 1 & 87 & \\
Yoghurt $(\mu \mathrm{g} / \mathrm{kg})$ & 5 & 147 & $115-179$ \\
Soured cream $(\mu \mathrm{g} / \mathrm{kg})$ & 5 & 87 & $44-176$ \\
Jarlsberg cheese $(\mu \mathrm{g} / \mathrm{kg})$ & 3 & 201 & $132-353$ \\
Norvegia cheese $(\mu \mathrm{g} / \mathrm{kg})$ & 3 & 414 & $169-468$ \\
Whey cheese§ $(\mu \mathrm{g} / \mathrm{kg})$ & 5 & 803 & $103-1360$ \\
\hline
\end{tabular}

LGG, Lactobacillus rhamnosus GG.

* Median value was significantly different to that for low-fat milk from the summer season $(P<0.001)$.

†Median value was significantly different to that for organic milk from the summer season (Mann-Whitney $U$ test for non-parametric samples, $P=0.02$ ).

$\ddagger$ Median value was significantly different to that for organic milk from the summer season $(P=0.006)$

$\S$ Tine Gudbrandalsost.

|| Biola, TINE, Oslo, Norway.
Representative samples of all types of milk (1 litre), yoghurt $(175 \mathrm{ml})$, soured cream $(300 \mathrm{ml})$ and cheese, casein and whey $(1 \mathrm{~kg})$ were shipped from each dairy to the National Institute of Nutrition and Seafood Research in Bergen in a cooled condition (approximately $+4^{\circ} \mathrm{C}$ ). An adequate amount of each sample was collected and frozen at $-20^{\circ} \mathrm{C}$ in $50 \mathrm{ml}$ screw-capped polyethylene centrifuge tubes until analysis. Before analysis, milk samples were left at room temperature to thaw. Cheese samples were crushed in a frozen condition to produce small particles. Both cheese and soured-cream samples were weighed in frozen condition.

\section{Sample preparation and analysis}

The determination of iodine in milk and dairy products was carried out using inductively coupled plasma-MS after digestion in tetra methyl ammonium hydroxide (Fecher et al. 1998). A test sample of $1 \mathrm{ml}$ milk or $0.1-0.2 \mathrm{~g}$ solid material was added to $5 \mathrm{ml}$ deionised water and $1 \mathrm{ml}$ tetra methyl ammonium hydroxide. Extraction was carried out in a dry oven at $90^{\circ} \mathrm{C} \pm 3^{\circ} \mathrm{C}$ for $3 \mathrm{~h}$. After cooling, $1 \mu \mathrm{g}$ Te was added as internal standard to the sample solution, which was then diluted to a final volume of $25 \mathrm{ml}$ with water. This gives a Te concentration in the solution analysed of $40 \mu \mathrm{g} / \mathrm{l}$. In order to avoid blocking of the nebuliser, all samples were filtered through a $0.45 \mu \mathrm{m}$ Sartorius Minisart RC 25 filter (Göttingen, Germany). A high degree of fat in the sample solution may cause problems; this was avoided by use of a syringe to extract solution before filtration. The iodine concentrations in the samples were determined by standard addition calibration (Julshamn et al. 2001). The use of an internal standard compensates for both random and systematic errors (Skoog, 1998). Te as an internal standard is preferred because of its low natural occurrence in biological material and good stability when analysed with inductively coupled plasma-MS (Eckhoff \& Maage, 1997).

All samples were analysed in duplicate using a PerkinElmer SCIEX Elan 5000A inductively coupled plasmamass spectrometer (Toronto, Canada). Optimisation and operating conditions of the instrument are described elsewhere (Julshamn et al. 2001).

Certified reference material is widely used to expose any systematic errors and assess the trueness of the analytical method in use, i.e. the degree of agreement between the certified value of an analyte and the mean value obtained from analysis (NMKL, 1996). Certified reference material was selected with regard to similarity in concentration and matrix to sample material analysed. For analyses of iodine in milk and dairy products, milk powder (BCR 150 spiked skimmed milk powder, Community Bureau of Reference, Brussels, Belgium) was chosen.

Measures of the trueness and repeatability (short-term precision) of the method were carried out by analysing ten parallels of the milk powder. The average obtained was 1.23 (SD 0.05$) \mathrm{mg} / \mathrm{kg}$ compared with the certified value of 1.29 (SD 0.09$) \mathrm{mg} / \mathrm{kg}$. The repeatability calculated as relative standard deviation (RSD \%) was $4 \%$. The internal reproducibility of the milk powder given as RSD (\%) was calculated as $11 \%$ and with an average iodine 
concentration of $1.19 \mathrm{mg} / \mathrm{kg}$ ( $n$ 30). The results show clearly that the analytical method in use is under control with regard to systematic and random error.

\section{Statistics}

Statistical analyses (one-way ANOVA and Student's $t$ test) were carried out using Statistica ${ }^{\mathrm{TM}}$ Software, release 4.5 (1999; StatSoft, Inc., Tulsa, OK, USA). A confidence level of $95 \%$ was used throughout all statistical tests, i.e. $P$ values below 0.05 were considered significant. Unless commented on, the data were tested for homogeneity of variance with Levene's test in a non-transformed way. In cases of organic milk, the data showed nonhomogeneity. Mann-Whitney $U$ tests for non-parametric samples were therefore used. In cases where ANOVA showed significant differences, post hoc tests were used to find which groups showed significant difference to each other. In cases where several groups were tested and the amount of samples was different, Tukey's honest significant difference test for different $n$ (Spjotvoll-Stoline test) was used. In the case of two groups, Student's $t$ test for independent samples was used. Pearson's correlation coefficient was calculated using the correlation function.

\section{Results}

\section{Seasonal differences in milk}

To observe seasonal differences, low-fat milks were, with one exception, collected from the same dairies during the summer and the winter seasons of 2000. The iodine concentration of low-fat milk produced during the summer period was found to be significantly lower than the iodine concentrations in low-fat milk produced during the winter period $(P<0.001$; Table 1$)$. Low-fat milk from the winter season showed less variation in the iodine concentration (CV 14.7\%) compared with low-fat milk sampled during the summer season (CV 18.3\%).

\section{Geographical location}

The iodine concentration of low-fat milk showed no significant differences between the five different regions (Fig. 1) within season (Table 1). Nevertheless, it became apparent that the iodine concentration in low-fat milk, to some degree, was dependent on the location of the dairy. Fig. 2 shows a significant correlation $(r \quad 0.60)$ between the iodine concentration in low-fat milk produced during the summer and the winter seasons $(P<0.01)$. This shows that a dairy with high iodine concentration in lowfat milk sampled during the winter season can be expected to lie in the highest range of iodine concentrations during the summer season.

\section{Milk from organic farms}

Organic milk was sampled from seven dairies during both seasons. The iodine concentration in organic milk from the winter period was significantly higher than organic milk from the summer period $(P=0.02$; Table 1$)$. Two dairies had high iodine concentrations in the organic milk sampled during the winter period; 365 and $264 \mu \mathrm{g} / \mathrm{l}$, respectively. The range of iodine concentration in organic milk from the summer season was much smaller than organic milk from the winter season. The median iodine concentration of organic milk sampled during both seasons was lower than non-organic milk (low-fat milk), the summer-season differences being significant $(P=0.006$; Table 2$)$.

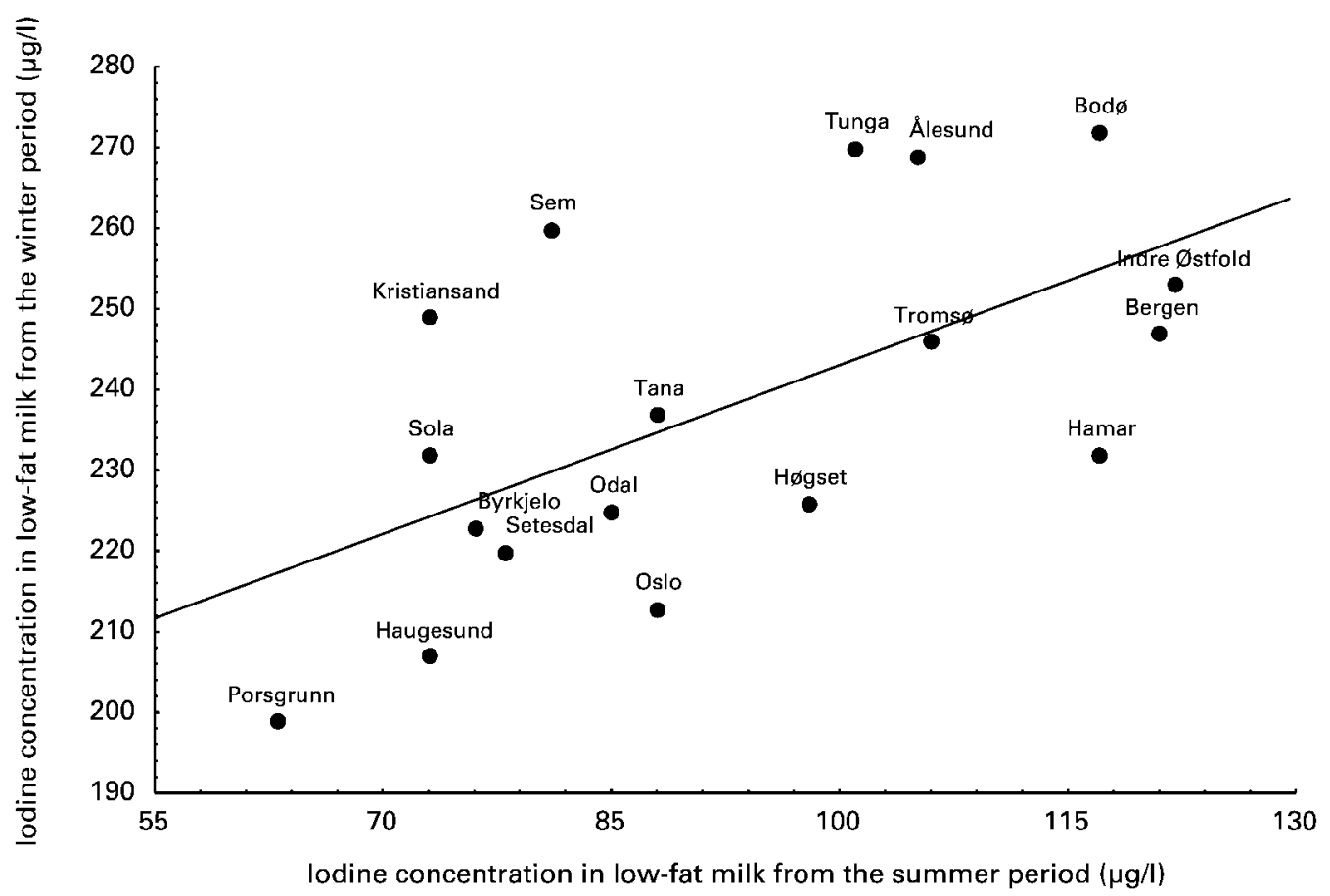

Fig. 2. Correlation between iodine concentrations in milk sampled during the summer and winter seasons of 2000 in Norway $(r 0.60 ; P<0.01)$. 


\section{Iodine concentrations in dairy products}

The production of dairy products is centralised and thus limited to certain dairies. The geographical range is therefore less for processed dairy products than for milk samples. The median and the range of iodine concentrations for processed dairy products are given in Table 2 . The results indicate that extra-low-fat milk and curdled milk products have similar concentration ranges of iodine as found in low-fat milk. Whey cheese (Tine Gudbrandsdalsost) showed the largest variation in iodine concentration of the dairy products. Jarlsberg cheese generally had a lower iodine concentration than Norvegia cheese, although the differences were not significant. The correlation between the iodine concentration in low-fat milk and the two dairy products (yoghurt and soured cream) produced at the same dairy was significant with correlation coefficients of 0.82 and 0.42 , respectively $(P<0.01)$

\section{Discussion}

The seasonal variation in the iodine content of milk was the main finding in the present study. The iodine concentration of low-fat milk found in the present study was higher than values reported in milk sampled from twelve places in Norway in 1971 (T Renaa and K Staveland, unpublished results); however, the seasonal variation showed the same pattern as has been described before ( $\mathrm{T}$ Renaa and $\mathrm{K}$ Staveland, unpublished results). The iodine concentration in milk sampled in 1971 had the lowest iodine concentration in the summer season $(65 \mu \mathrm{g} / \mathrm{l})$ in the inland areas and the highest iodine concentration in milk during the winter season $(120 \mu \mathrm{g} / \mathrm{l}$; $\mathrm{T}$ Renaa and K Staveland, unpublished results). Thus, it seems that the iodine concentration of milk has increased in the last 30 years, especially during the winter months. However, the samples were not taken from the exact same dairies in the two studies and results are therefore not directly comparable.

The seasonal variations in the iodine content of milk are usually attributed to the proportion of pasture feeding $v$. the use of cow fodder fortified with iodine (Pennington, 1990). The higher iodine content of winter milk in the present study can be explained by the iodine fortification of cow feed and is in accordance with a number of other studies (Wenlock et al. 1982; Pennington, 1990; Lee et al. 1994; Ministry of Agriculture, Fisheries and Food, 1997, 1999; Phillips, 1997; Larsen et al. 1999). The iodine content of milk reported recently in the UK (Ministry of Agriculture, Fisheries and Food, 2000) was on average $430 \mu \mathrm{g} / \mathrm{l}$ in winter, while summer milk contained $200 \mu \mathrm{g} / \mathrm{l}$. Two studies from Denmark showed both geographical and seasonal variations in the iodine content of milk (Larsen et al. 1999; Rasmussen et al. 2000). A study from the USA (Pennington, 1990) showed that the western parts of the continent had a higher iodine concentration in milk $(340 \mu \mathrm{g} / \mathrm{l})$ than milk from the eastern parts $(160 \mu \mathrm{g} / \mathrm{l})$. These differences were found in milk from the summer season (Pennington, 1990).

Binnerts (1979) has suggested that higher concentrations of iodine in the winter months might reflect decreased milk production. Other studies have claimed that iodine may occur in milk as a result of the use of iodophors as cow teat sterilants and equipment sanitisers in dairies (Franke et al. 1983; Galton et al. 1986; Pennington, 1990). According to Hemken (1979) iodine test dips and sanitisers contribute an insignificant amount to increase the iodine content in milk, unless they are improperly used. The dairies in Norway do not use sanitisation or disinfectant containing iodophores.

The smaller variation of the iodine content in low-fat milk from the winter season compared with the summer milk indicates that cow fodder containing iodine is widely used by farmers in Norway. Even though cows are fed with different brands of fodder, the fortification of iodine $(2 \mathrm{mg} / \mathrm{kg})$ is stable and supplies the cows with a standardised amount of iodine.

Although both precipitation and iodine concentrations in the soil vary in Norway (Låg \& Steinnes, 1976), these variations were not reflected in the iodine concentrations of milk within season in the present study. The relationship between the iodine concentration in low-fat milk sampled during the summer and winter seasons (Fig. 2) indicates that the farming practices vary within small ranges in the five different geographical locations. The larger variation of the iodine content in milk from the summer season compared with the winter milk is probably accounted for by a longer period of pasture feeding in the South and East regions of Norway combined with differences in the access to iodine-fortified cow fodder during the summer season. In Denmark the regional differences in milk within season were due to differences in the iodine content in the drinking-water resources (Larsen et al. 1999). The iodine concentration in drinking water in Norway is on average less than $2 \mu \mathrm{g} / \mathrm{l}$ (L Dahl, HM Meltzer, $\mathrm{L}$ Johansson and $\mathrm{K}$ Julshamn, unpublished results) and contributes in all probability very little to the iodine content of the milk.

The iodine level in organic milk was expected to be more or less dependent on the iodine concentration of pastureland. Results from the present study showed a wide range of iodine concentrations in organic milk sampled during the winter season $(34-367 \mu \mathrm{g} / \mathrm{l})$. The iodine concentrations in organic milk from both summer and winter seasons were in general lower than the iodine concentration in non-organic milk from the same season. The observed differences between organic milk and non-organic milk (low-fat milk) may display the effect of the variable use of feed to the cows. Farms producing organic milk are allowed to use mineral mixtures and give cows iodine-enriched fodder up to $20 \%$ feed energy, according to Norwegian national regulations in the field (Debio, 2003). Organic milk producers also frequently use fodder containing seaweed meal. However, the exact influence cattle fodder has on the iodine level in non-organic milk is difficult to estimate since type and amount of fodder used has not been monitored. According to a study from Denmark (Rasmussen et al. 2000), which shows similar seasonal differences between organic and non-organic milk, the differences can mainly be explained by the variation in feeding practices. 
Iodine levels in dairy products are expected to be in the same concentration range as the raw material. Studies have shown minimal losses during different processing methods of milk, such as pasteurisation and skimming (Pedriali et al. 1997). The great variation in iodine content found in whey cheese (Tine Gudbrandsdalsost) reflects in all probability the use of milk from different seasons, as the storage of the cheese before sale was not registered. Whey cheese also contains added goats' milk. The influence goats' milk has on the iodine concentration in whey cheese is unknown since it was not analysed for iodine. It should be commented that during the production of whey cheese the whey is boiled in order to remove water (resulting in $560-580 \mathrm{~g} \mathrm{DM} / \mathrm{kg}$ ). This will obviously increase the concentration of iodine in the remaining product and explains the higher iodine concentration in whey cheese. Iodine compounds are soluble in water; it is therefore probable that whey cheese contains more iodine than cheese made from casein (Jarlsberg and Norvegia).

Knowledge about the variation in iodine concentration of milk and dairy products is important as the consumption of milk and dairy products is very common in Norway (Johansson \& Solvoll, 1999). According to a nationwide dietary survey among 2672 representative adult Norwegians in 1997 the mean intake of milk was 438 (SD $319) \mathrm{g} / \mathrm{d}$ per individual with a median value of $375 \mathrm{~g} / \mathrm{d}$ (Johansson \& Solvoll, 1999). Assuming a relatively stable intake of milk during a year, the iodine level in Norwegian milk alone will meet the daily recommendations of iodine set at $150 \mu \mathrm{g}$ with $25 \%$ during the summer and with more than $60 \%$ during the winter season. In addition, dairy products will contribute substantially.

In conclusion, a seasonal variation in iodine content of milk was found in Norway. The highest content of iodine was found in samples from the winter season and reflects the use of cow fodder fortified with iodine. Milk and dairy products are important determinants of iodine intake in Norway.

\section{Acknowledgements}

Milk and dairy products were kindly given by TINE Norske Meierier, Oslo, Norway. The Norwegian Research Council is thanked for financially supporting this work (project no. 120824/112). The authors would also like to thank Berit Engen Solli and Jan Brenna for their technical assistance with iodine analysis.

\section{References}

Baumann H (1990) Rapid and sensitive determination of iodine in fresh milk and milk powder by inductively coupled plasmamass spectrometry (ICP-MS). Frensenius J Anal Chem 338, 809-812.

Binnerts WT (1979) The iodine content of milk: no reason for concern yet. Neth Milk Dairy J 33, 12-23.

Delange F (1994) The disorders induced by iodine deficiency. Thyroid 4, 107-128.

Debio (2003) English homepage for Debio - Certification of organic agricultural production. http://www.debio.no/diverse/ deb_eng.htm

Eckhoff KM \& Maage A (1997) Iodine content in fish and other food products from East Africa analysed by ICP-MS. $J$ Food Comp Anal 10, 270-282.

Fecher PA, Goldmann I \& Nagengast A (1998) Determination of iodine in food samples by inductively coupled plasma mass spectrometry after alkaline extraction. J Anal At Spectrom 13, 977-982.

Franke AA, Bruhn JC \& Osland RB (1983) Factors affecting iodine concentration of milk of individual cows. J Dairy Sci 66, 997-1002.

Frey H (1986) Iodine status in Scandinavia. Acta Pharmacol Toxicol (Copenh) 59, Suppl. 7, 111-115.

Frey H, Rosenlund B, Try K \& Thodorsen L (1993) Urinary excretion of iodine in Norway. In Iodine Deficiency in Europe, pp. 297-300 [F Delange, editor]. New York, NY: Plenum Press.

Galton DM, Petersson LG \& Erb HN (1986) Milk iodine residues in herds practicing iodophors premilking teat disinfection. J Dairy Sci 69, 267-271.

Hemken RW (1979) Factors that influence the iodine content of milk and meat: a review. J Anim Sci 48, 981-985.

Hetzel BS (1983) Iodine deficiency disorders (IDD) and their eradication. Lancet ii, 1126-1129.

Johansson L \& Solvoll K (1999) The Norkost Survey 1997: National Dietary Survey among Males and Females, 16-79 Years. Report 2 (in Norwegian). Oslo, Norway: The National Council on Nutrition and Physical Activity.

Julshamn K, Dahl L \& Eckoff K (2001) Determination of iodine in seafood by inductively coupled plasma/mass spectrometry. J AOAC Int 84, 1976-1983.

Karl H \& Munker W (1999) Iod in marinen Lebensmitteln (Iodine in marine food). Ernahr Umsch 46, 288-291.

Låg J \& Steinnes E (1976) Regional distribution of halogens in Norwegian forest soils. Geoderma 16, 317-325.

Larsen EH, Knuthsen P \& Hansen M (1999) Seasonal and regional variations of iodine in Danish dairy products determined by inductively coupled plasma mass spectrometry. $J$ Anal At Spectrom 14, 41-44.

Lee SM, Lewis J, Buss D, Holcombe GD \& Lawrance PR (1994) Iodine in British foods and diets. Br J Nutr 72, 435-446.

Ministry of Agriculture (1996) Regulation of husbandry practising for cattle and swine (in Norwegian). http://www. lovdata.no/for/sf/ld/ld-19960115-0091.html

Ministry of Agriculture (2002) Regulation of feeding stuff (in Norwegian). http://www.lovdata.no/for/sf/ld/ld-200211071290.html

Ministry of Agriculture, Fisheries and Food (1997) Nutrient Analysis of Liquid Pasteurised Milk. Food Surveillance Information Sheet no. 128. London: HM Stationery Office.

Ministry of Agriculture, Fisheries and Food (1999) Nutrient Analysis of Other Milks and Creams. Food Surveillance Information Sheet no. 178. London: HM Stationery Office.

Ministry of Agriculture, Fisheries \& Food (2000) Iodine in Milk. Food Surveillance Information Sheet no. 196. London: HM Stationery Office.

Ministry of Health (2002) Regulation of general production of food offered to consumers (in Norwegian). http://www.snt.no/ rettsregler/forskrifter/hd-19830708-1252.html

NMKL (1996) Validation of Chemical Analytical Methods no. 4. Oslo, Norway: Nordic Committee on Food Analysis.

NNR (1996) Nordic Dietary Recommendations (in Swedish). Copenhagen: Nordic Council of Ministers, Nord 1996:28.

Pedriali R, Giuliani E, Margutti A \& Uberti ED (1997) Iodine assay in cow milk - Industrial treatments and iodine concentration. Annali di Chimica 87, 449-456. 
Pennington JAT (1990) Iodine concentrations in US milk: variation due to time, season and region. J Dairy Sci 73, 3421-3427.

Phillips DIW (1997) Iodine, milk and the elimination of endemic goitre in Britain: the story of an accidental public health triumph. J Epidemiol Community Health 51, 391-393.

Rasmussen LB, Larsen EH \& Ovesen L (2000) Iodine content in drinking water and other beverages in Denmark. Eur J Clin Nutr 54, 57-60.

Skoog DA (1998) Principles of Instrumental Analysis, pp. 116-271. Philadelphia, PA: Saunders.
Varo P, Saari E, Passo A \& Koivitoinen P (1982) Iodine in Finnish foods. Int $J$ Vitam Nutr Res 52, 80-89.

Wenlock RW, Buss DH, Moxon RE \& Bunton NG (1982) Trace element in British food. Br J Nutr 47, 381-390.

World Health Organization (1996) Iodine Deficiency Disorders Fact Sheet no. 121. http://www.who.int/inf-fs/en/fact121.html

World Health Organization (1994) WHO, UNICEF, ICCIDD Indicators for Assessing Iodine Deficiency Disorders and their Control through Salt Iodisation, pp. 1-55. Geneva, Switzerland: WHO. 